\title{
Metabolism of Amines
}

\section{THE DEGRADATION AND SYNTHESIS OF $\gamma$-AMINOBUTYRIC ACID BY PSEUDOMONAS AERUGINOSA*}

\author{
BY U. BACHRACH \\ Department of Clinical Microbiology, Hebrew University-Hadassah Medical School, Jerusalem, Israel
}

\author{
(Received 9 May 1960)
}

The degradation of spermine and spermidine by various bacteria has been described by Razin, Gery $\&$ Bachrach (1959). $\gamma$-Aminobutyric acid, an intermediate in these degradations, could be further metabolized by transamination, by washed cell suspensions of Pseudomonas aeruginosa and Mycobacterium smegmatis (Bachrach, Persky \& Razin, 1960). This study deals with the mechanism of $\gamma$-aminobutyric acid degradation by cell-free preparations of $P$. aeruginosa, and the reversal of this process.

\section{MATERIALS AND METHODS}

Organism. The strain of $P$. aeruginosa used throughout this study was the one described by Razin et al. (1959).

Medium. P. aeruginosa was grown on a medium composed of: yeast extract (Difco), $1 \mathrm{~g}$; $\mathrm{K}_{2} \mathrm{HPO}_{4}, 2 \mathrm{~g}$.; $\mathrm{KH}_{2} \mathrm{PO}_{4}, 1$ g.; $\mathrm{MgSO}_{4}, 7 \mathrm{H}_{2} \mathrm{O}, 0 \cdot 2$ g.; $\gamma$-aminobutyric acid, 3 g.; agar, 15 g.; water, 1 l. The final $\mathrm{pH}$ was $7 \cdot 2$.

Cell suspensions and enzyme preparations. Bacteria grown on the medium specified above for $20 \mathrm{hr}$. at $37^{\circ}$ were harvested, washed twice with $0.85 \% \mathrm{NaCl}$ soln. and kept at $4^{\circ}$ until used. Freeze-dried cells were obtained by drying the bacteria over $\mathrm{P}_{2} \mathrm{O}_{5}$ at $0.3 \mathrm{~mm} . \mathrm{Hg}$ in a centrifugal freeze-drier (W. Edwards and Co. Ltd., Crawley, Sussex, England). Cell-free preparations were obtained by subjecting washed cell suspensions to the action of a 10 kcyc. Raytheon sonic oscillator for $20 \mathrm{~min}$. The intact cells and debris were removed by centrifuging at $11000 \mathrm{~g}$ for $20 \mathrm{~min}$. Coenzyme $A$ was removed by adsorption on Amberlite IRA-400 (Chantrenne, 1951).

Chemicals. $\gamma$-Aminobutyric acid, oxaloacetic acid, $\alpha$ oxovaleric acid, diphosphopyridine nucleotide (DPN), triphosphopyridine nucleotide (TPN) and coenzyme A (CoA) were the products of Nutritional Biochemicals Corp., Cleveland, Ohio, U.S.A. $\alpha$-Oxoglutaric acid was obtained from L. Light and Co. Ltd., Colnbrook, Bucks., England, alcohol dehydrogenase was produced by Worthington Biochemical Corp., Freehold, N.J., U.S.A. and $\left[1: 4^{-14} \mathrm{C}\right]-$ succinic acid was purchased from The Radiochemical Centre, Amersham, Bucks. Succinic semialdehyde was prepared according to Prescott \& Waelsch (1946).

Buffer solutions. The phosphate buffers were mixtures of $0.067 \mathrm{M}-\mathrm{Na}_{2} \mathrm{HPO}_{4}$ and $0.067 \mathrm{M}-\mathrm{KH}_{2} \mathrm{PO}_{4}$.

Manometric methods. Manometric experiments were carried out as described by Razin et al. (1959). The gas phase was $\mathrm{H}_{2}$ in anaerobic experiments. The dehydrogenase activity of the cell-free preparation was determined by the Thunberg method (Umbreit, Burris \& Stauffer, 1957).

* Part 2: Bachrach, Persky \& Razin (1960).
Identification of amines. This was carried out by paper chromatography. Butanol-acetic acid-water (50:25:25, by vol.) (Baker, Harborne \& Ollis, 1952) was the standard solvent used. The other solvents included: ethanol, $70 \%$ (v/v) (Miller \& Rockland, 1952); pyridine-acetic acidwater (50:35:15, by vol.) (Decker \& Riffart, 1950); $95 \%$ ethanol-amyl alcohol-water $(70: 50: 30$, by vol.). The papers were sprayed with $0 \cdot 2 \%(w / v)$ ninhydrin in butanol. The amines were quantitatively assayed according to Giri, Radhakrishnan \& Vaidyanathan (1952). $\gamma$-Aminobutyric acid was also identified by paper chromatography, by the method of Kalyankar \& Snell (1957). Dinitrophenyl derivatives of the amines or amino acids were prepared according to Rosenthal \& Tabor (1956) and analysed by paper chromatography, the solvent being either butanol saturated with ammonia or a $0.067 \mathrm{M}$-phosphate buffer, pH 6.0 (Kojima, Mizuno \& Miyazaki, 1958).

Identification of aldehydes and keto acids. 2:4-Dinitrophenylhydrazones of the aldehydes or keto acids were prepared and analysed by paper chromatography according to Block, Durrum \& Zweig (1958). The solvents used were: butanol-ethanol-0.5 $\mathrm{N}-\mathrm{NH}_{3}$ soln. (70:10:20, by vol.) (El Hawary \& Thompson, 1953), and butanol-ethanol (80:20, v/v) (Cavallini, Frontali \& Toschi, 1949). The papers were sprayed with $2 \%(w / v) \mathrm{KOH}$ in ethanol.

Spectrophotometric analysis. Reduced DPN or TPN were quantitatively determined by the spectrophotometric method (Racker, 1950), with a Unicam SP. 500 spectrophotometer. Proteins were quantitatively estimated by the spectrophotometric method (Layne, 1957).

Identification and assay of labelled compounds. $\gamma$-Aminobutyric acid or succinic semialdehydes were identified by paper chromatography and the radioactive areas located on the paper were counted either directly with a mica endwindow Geiger-Müller tube, or eluted with water and assayed for radioactivity on planchets with an end-window, lead-shielded Geiger-Müller tube (Tracerlab).

\section{RESULTS}

Transamination of $\gamma$-aminobutyric acid. $\gamma$-Aminobutyric acid was oxidized slowly by washed cells of $P$. aeruginosa. Its oxidation by freeze-dried cells was even slower. Cell-free preparations metabolized $\gamma$-aminobutyric acid in the presence of various keto acids. Table 1 shows that oxaloacetate and $\alpha$-oxovalerate both participated in the transamination, as shown with $\alpha$-oxoglutarate and pyruvate (Bachrach et al. 1960). The pH optimum for the transamination of $\gamma$-aminobutyric acid with 
$\alpha$-oxoglutarate by cell suspensions was $7 \cdot 6$ (Fig. 1 ). The succinic semialdehyde produced from $\gamma$ aminobutyric acid was identified by paper chromatography, as described by Bachrach et al. (1960).

Metabolism of $\gamma$-aminobutyric acid by cell-free preparations. Cell-free preparations did not oxidize $\boldsymbol{\gamma}$-aminobutyric acid and the addition of boiled debris did not result in a marked oxygen uptake. On the other hand, methylene blue was reduced anaerobically by cell-free preparations in the presence of $\gamma$-aminobutyric acid and $\alpha$-oxoglutarate. Reduction of TPN occurred when it was added to a reaction mixture containing cell-free preparation, $\gamma$-aminobutyric acid and $\alpha$-oxoglutarate, as shown by the characteristic appearance of the $340 \mathrm{~m} \mu$

Table 1. Transamination of $\gamma$-aminobutyric acid by cell-free preparations in the presence of various keto acids

Each Warburg vessel contained $20 \mu$ moles of $\gamma$-aminobutyric acid, $20 \mu$ moles of keto acids, $1 \mathrm{ml}$. of cell-free preparations (approx. $4 \mathrm{mg}$. of protein) and $1 \mathrm{ml}$. of

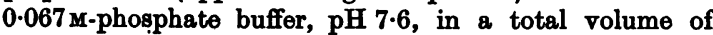
$3.2 \mathrm{ml}$. Incubation was in $\mathrm{H}_{2}$ at $37^{\circ}$ for $200 \mathrm{~min}$. The amino acids produced from the corresponding keto acids were determined by quantitative paper chromatography.

\begin{tabular}{|c|c|}
\hline Keto acids added & $\begin{array}{c}\text { Amino acids produced } \\
(\mu \text { moles })\end{array}$ \\
\hline $\begin{array}{l}\alpha \text {-Oxoglutarate } \\
\text { Pyruvate } \\
\text { Oxaloacetate } \\
\alpha \text {-Oxovalerate }\end{array}$ & $\begin{array}{lr}\text { Glutamate } & 8.0 \\
\text { Alanine } & 5 \cdot 5 \\
\text { Aspartate } & 4 \cdot 2 \\
\text { Valine } & 1 \cdot 6\end{array}$ \\
\hline
\end{tabular}

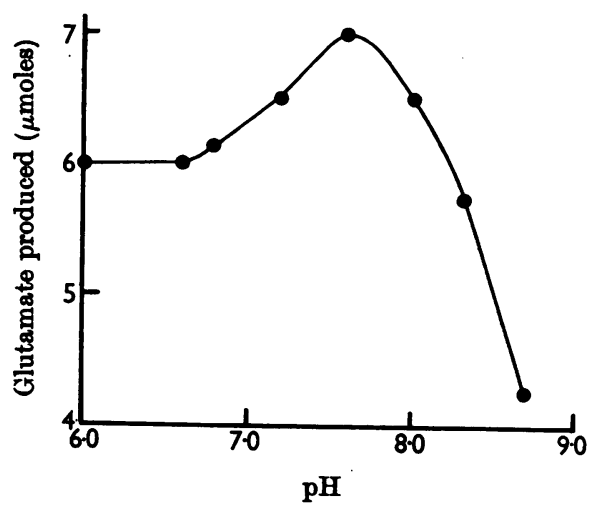

Fig. 1. Effect of $\mathrm{pH}$ on the transamination of $\gamma$-aminobutyric acid by cell suspensions. Each Warburg vessel contained $10 \mu$ moles of $\gamma$-aminobutyric acid, $10 \mu \mathrm{moles}$ of $\alpha$-oxoglutarate, $1 \mathrm{ml}$. of bacterial suspensions (approx. $5 \mathrm{mg}$. dry wt.) and $1 \mathrm{ml}$. of $0.067 \mathrm{M}$-phosphate buffer, $\mathrm{pH} \mathrm{7.3}$, in a total volume of $3.2 \mathrm{ml}$. Incubation was in $\mathrm{H}_{2}$ at $30^{\circ}$ for $200 \mathrm{~min}$. The amount of glutamate produced was determined by quantitative paper chromatography. band. DPN was slowly reduced under similar conditions (Fig. 2). With succinic semialdehyde as substrate, the rate of reduction was higher. The oxidation of succinic semialdehyde seems to require the presence of some cofactors. A cell-free preparation which was dialysed overnight against 4 1. of distilled water at $4^{\circ}$ retained its ability to transaminate $\boldsymbol{\gamma}$-aminobutyric acid, whereas no marked reduction of TPN occurred in the presence of succinic semialdehyde. The treatment of a cellfree preparation with Amberlite IRA-400, which is known to remove CoA, did not affect transamination, but the reduction of TPN was markedly inhibited (Fig. 3).

The interaction between succinic semialdehyde and TPN or DPN should give rise to succinic acid. No succinate could, however, be detected in the reaction mixture by paper chromatography. Succinate might be formed as an intermediate product, without being accumulated, and an attempt was made to demonstrate its participation in the metabolism of $\gamma$-aminobutyric acid by the reversal of the degradation process. Succinic acid (100 $\mu$ moles) was incubated for $60 \mathrm{~min}$. with a cellfree preparation of $P$. aeruginosa (approx. $4 \mathrm{mg}$. of protein) in the presence of $20 \mu$ moles of glutathione, $10 \mu$ moles of magnesium sulphate, $1 \mu \mathrm{mole}$ of DPN, $0.3 \mathrm{ml}$. of ethanol, $100 \mu \mathrm{g}$. of alcohol dehydrogenase and $1 \mathrm{ml}$. of $0.067 \mathrm{M}$-phosphate buffer, pH 7.2. Succinic semialdehyde was shown to be formed by paper chromatographic analysis. The semialdehyde formed was converted into $\gamma$-aminobutyric acid in the presence of glutamate or $\alpha$ alanine. The identity of $\gamma$-aminobutyric acid in all these experiments was confirmed by paper chromatography with four different solvents, and by

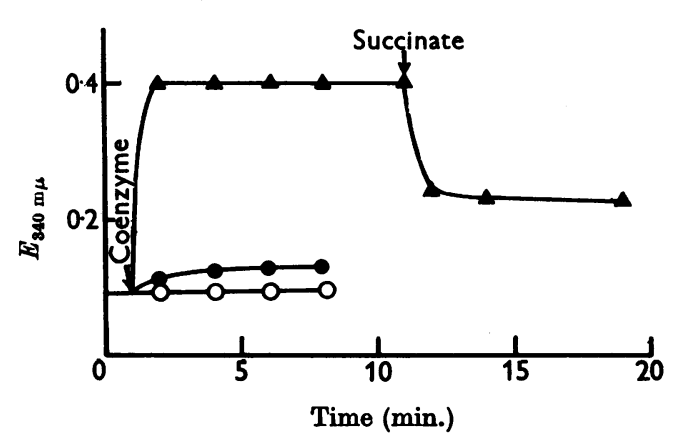

Fig. 2. Oxidation of succinic semialdehyde in the presence of pyridine nucleotides. The reaction mixture contained: $20 \mu$ moles of $\gamma$-aminobutyric acid, $20 \mu$ moles of $\alpha$-oxoglutarate, $2.5 \mathrm{ml}$. of cell-free preparations (approx. $4 \mathrm{mg}$. of protein) and $1 \mathrm{ml}$. of $0.067 \mathrm{M}$-phosphate buffer, $\mathrm{pH} 7.3$. After $30 \mathrm{~min}$. incubation at $37^{\circ}$, water $(O)$ or $2 \mu$ moles of TPN (A) or DPN (O) was added to $1 \mathrm{ml}$. of reaction mixture and examined spectrophotometrically. Succinate (25 $\mu$ moles) was added as indicated after another $10 \mathrm{~min}$. 


\section{Table 2. Formation of ${ }^{14} \mathrm{C}$-labelled compounds by reduction of $\left[{ }^{14} \mathrm{C}\right]$ succinate}

The reaction mixture contained $15 \mu$ moles of $\gamma$-aminobutyric acid, $15 \mu$ moles of $\alpha$-oxoglutarate, 2 ml. of cell-free preparations (approx. $5 \mathrm{mg}$. of protein), and $1 \mathrm{ml}$. of $0.067 \mathrm{M}$-phosphate buffer, $\mathrm{pH} \mathrm{7.3.} \mathrm{After} \mathrm{incubation} \mathrm{for}$ $30 \mathrm{~min}$. at $37^{\circ}$ in air, $2 \mu$ moles of TPN, $50 \mu$ moles of [ $\left.{ }^{14} \mathrm{C}\right]$ succinate $\left(3 \times 10^{5}\right.$ counts $\left./ \mathrm{min}.\right), 10 \mu \mathrm{moles}$ of $\mathrm{MgSO}_{4}$ and $20 \mu$ moles of glutathione were added. The reaction mixture was kept at $37^{\circ}$ for 20 min. and examined by paper chromatography. The corresponding spots were eluted and assayed for radioactivity.

Compound formed

Succinic semialdehyde

$\gamma$-Aminobutyric acid
Solvent system

Butanol-ethanol-ammonia

Ethanol-amyl alcohol-water Butanol-acetic acid-water $70 \%$ Ethanol
Radioactivity (counts/min./ml. of reaction mixture)

1819

19780

16340

12330

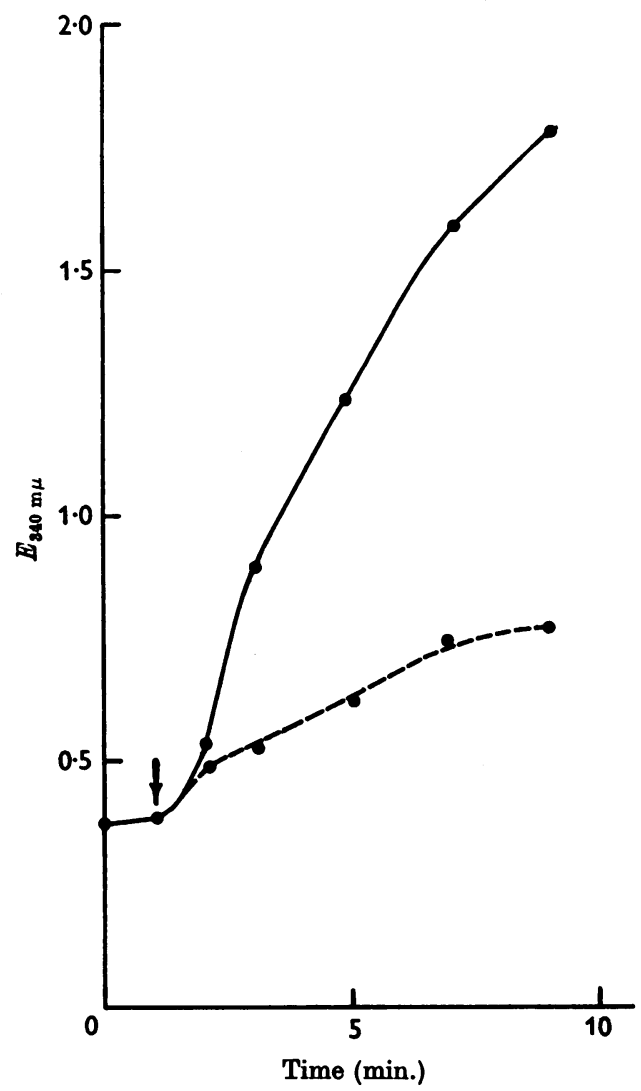

Fig. 3. Oxidation of succinic semialdehyde by various cell-free preparations. The reaction mixture contained: $10 \mu$ moles of $\gamma$-aminobutyric acid, $10 \mu$ moles of $\alpha$-oxoglutarate, $2 \mathrm{ml}$. of cell-free preparations (approx. $5 \mathrm{mg}$. of protein) and $1 \mathrm{ml}$. of $0.067 \mathrm{M}$-phosphate buffer, pH 7.3. After incubation for $30 \mathrm{~min}$. at $37^{\circ}, 2 \mu$ moles of TPN were added to the reaction mixtures (indicated by the arrow) and examined spectrophotometrically. - Cell-free preparation; -. -, cell-free preparation treated with Amberlite IRA-400. the technique described by Kalyankar \& Snell (1957) which is specific for $\gamma$ - and $\beta$-amino compounds. 2:4-Dinitrophenyl derivatives were also prepared and analysed by paper chromatography with two different solvents.

The conversion of succinate into $\gamma$-aminobutyric acid was confirmed by the use of ${ }^{\left[{ }^{14} \mathrm{C}\right] \text { succinate, }}$ which was reduced as above with reduced DPN by cell-free preparations of $P$. aeruginosa. The reaction mixture contained $50 \mu$ moles of $\left[{ }^{14} \mathrm{C}\right]$ succinic acid $\left(3 \times 10^{5}\right.$ counts $/$ min. $), 20 \mu$ moles of glutathione, $10 \mu \mathrm{moles}$ of magnesium sulphate, $5 \mu$ moles of DPN, $0.2 \mathrm{ml}$. of ethanol, $50 \mu \mathrm{g}$. of alcohol dehydrogenase, $1 \mathrm{ml}$. of $0.067 \mathrm{M}$-phosphate buffer, $\mathrm{pH} 7 \cdot 2$, and $2 \mathrm{ml}$. of cell-free preparation (approx. 7.0 mg. of protein); the total volume was $4.0 \mathrm{ml}$. During the $90 \mathrm{~min}$. incubation at $37^{\circ}$, $\left[{ }^{14} \mathrm{C}\right]$ succinic semialdehyde was produced. This compound was identified by paper chromatography of the 2:4-dinitrophenylhydrazones with butanolethanol-ammonia as solvent. Its radioactivity was 13624 counts/min.

Reduced TPN, which was more active in the reduction of succinate, was also tested. A cell-free preparation of $P$. aeruginosa was incubated with $\gamma$-aminobutyric acid and $\alpha$-oxoglutarate; TPN was then added to the reaction mixture containing the semialdehyde and formation of reduced TPN was observed. On addition of $\left[{ }^{14} \mathrm{C}\right]$ succinate to the reaction mixture, now containing reduced TPN, $\left[{ }^{14} \mathrm{C}\right]$ succinic semialdehyde and $\gamma$-amino $\left[{ }^{14} \mathrm{C}\right]$ butyric acid were formed. The formation of $\gamma$. amino $\left[{ }^{14} \mathrm{C}\right]$ butyric acid was demonstrated by peper chromatography with three different solvent systems (Table 2). As expected, the addition of succinate to the reaction mixture containing reduced TPN caused the immediate oxidation of the reduced coenzyme (see Fig. 2). Samples of a reaction mixture obtained during the reduction of succinate by reduced DPN were analysed by paper chromatography and showed a ninhydrin- 
positive spot of $R_{F} 0.69$ with the standard butanolacetic acid-water solvent system. The compound responsible for this spot did not react as an aldehyde; it was presumed to be a reduction product of $\gamma$-aminobutyric acid, probably an amino alcohol. Synthetic 4-aminobutan-1-ol behaved chromatographically like the reduction product and was oxidized by cell suspensions to a compound behaving as $\gamma$-aminobutyric acid when examined by paper chromatography with the standard butanol-acetic acid-water solvent system.

Effect of inhibitors on $\gamma$-aminobutyric acid degradation. The activity of various inhibitors on the oxidation of $\gamma$-aminobutyric acid was examined. Iodoacetate, hydroxylamine and semicarbazide almost completely inhibited the oxidation of $\gamma$ aminobutyric acid by freeze-dried cells of $P$. aeruginosa (Table 3). Iodoacetate inhibited the oxidation of $\gamma$-aminobutyric acid by washed cell suspensions to a smaller degree. Transamination of $\gamma$-aminobutyric acid with $\alpha$-oxoglutarate was not inhibited by iodoacetate $(0.3 \mathrm{~mm})$, as measured by glutamic acid and succinic semialdehyde formation. Arsenite inhibited the $\gamma$-aminobutyric acid oxidation by freeze-dried cells by $90 \%$ (Table 3 ). Transamination was not inhibited under these conditions.

Table 3. Effect of inhibitors on the oxidation of $\gamma$-aminobutyric acid by cell suspensions

Each Warburg vessel contained $10 \mu$ moles of $\gamma$-aminobutyric acid, $0.5 \mathrm{ml}$. of inhibitor, freeze-dried cells $(10 \mathrm{mg}$. dry wt.), and $1 \mathrm{ml}$. of $0.067 \mathrm{M}$-phosphate buffer, $\mathrm{pH} 7 \cdot 3$. The centre well contained $0.2 \mathrm{ml}$. of $15 \%(\mathrm{w} / \mathrm{v}) \mathrm{KOH}$. Total volume was $3.2 \mathrm{ml}$. Incubation was in air at $37^{\circ}$ for $120 \mathrm{~min}$.

\begin{tabular}{lcc}
\multicolumn{1}{c}{ Inhibitor } & $\begin{array}{c}\text { Concn. } \\
(\mathrm{mM})\end{array}$ & $\begin{array}{c}\text { Inhibition of } \\
\mathrm{O}_{2} \text { uptake } \\
(\%)\end{array}$ \\
Ioduacetate & $0 \cdot 3$ & 100 \\
Hydroxylamine & $0 \cdot 3$ & 96 \\
Semicarbazide & $0 \cdot 3$ & 92 \\
Arsenite & $0 \cdot 01$ & 90 \\
isoNicotinic acid hydrazide & 0.5 & 62
\end{tabular}

\section{DISCUSSION}

The metabolism of $\gamma$-aminobutyric acid by bacterial enzyme systems has been studied by various authors. Because of the stimulatory effect produced by the addition of different keto acids, it is generally believed that the first step in its break. down is its transamination.

In a strain of Achromobacter, $\alpha$-oxoglutarate and oxaloacetate were the active keto acids (Highashi, Horio \& Okunuki, 1957). A strain of Pseudomonas described by Scott \& Jakoby (1958) was able to transaminate $\gamma$-aminobutyric acid in the presence of $\alpha$-oxoglutarate only. Similar results were obtained by Noe \& Nickerson (1958) with a strain of $P$. aeruginosa, isolated from soil, and by Bacillus pumilus (Tsunoda \& Shiio, 1959). The present investigation confirms these results and supports the view that succinic semialdehyde is formed. The strain of $P$. aeruginosa used in the present study could use $\alpha$-oxoglutarate, pyruvate, oxaloacetate or $\alpha$-oxovalerate as keto acids in the transamination reaction. The oxidation of succinic semialdehyde by homogenates of rat brain is catalysed by DPN (Albers \& Salvador, 1958), whereas TPN was active in the oxidation of succinic semialdehyde by a Pseudomonas strain (Scott \& Jakoby, 1958). Our studies indicate that both TPN or DPN may take part in the oxidation of succinic semialdehyde, although the latter was less active. Results presented in this paper indicate that the oxidation of $\gamma$-aminobutyric acid by cell-free preparations of $P$. aeruginosa proceeds along the pathway outlined in Fig. 4. $\gamma$-Aminobutyric acid is converted into succinic semialdehyde by transamination, in the presence of various keto acids. Succinic semialdehyde is oxidized by TPN or DPN to a compound on the succinate level (perhaps succinyl-CoA). Succinate, which could not be isolated during the oxidation of $\gamma$-aminobutyric acid by cell-free preparations of $P$. aeruginosa, accumulated during the oxidation of $\gamma$-amino-

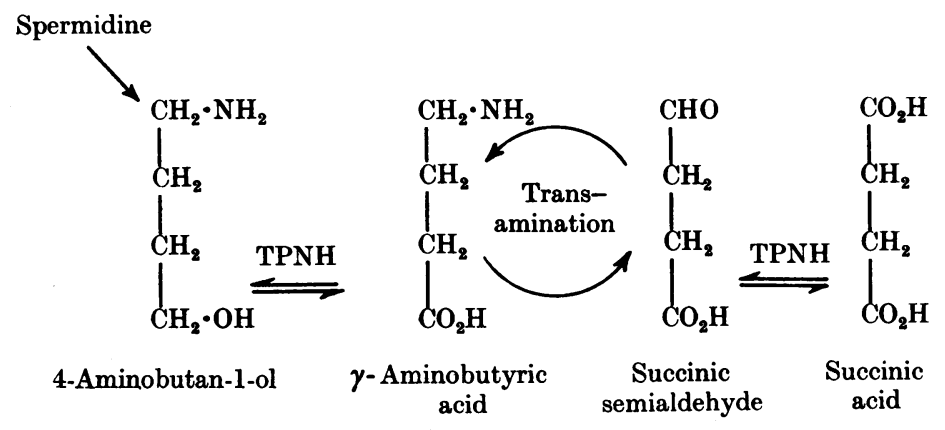

Fig. 4. Reductive amination of succinate. 
butyric acid by $M$. smegmatis (Bachrach et al. 1960). It is likely that CoA is necessary for the oxidation of succinic semialdehyde, since removal of CoA by treatment of the bacterial preparation with Amberlite IRA-400 resulted in loss of activity. The inhibitory effect exerted by iodoacetate and dialysis points to the possibility that $\mathrm{SH}$ groups play a role in the oxidation. Jakoby \& Scott (1959) have already demonstrated the importance of $\mathrm{SH}$ groups in the oxidation of succinic semialdehyde by $P$. fluorescens. The pathway of $\gamma$-aminobutyric acid degradation may be reversed, and succinic acid may serve as a precursor (see Fig. 4). The reductive amination of succinate to $\gamma$-aminobutyric acid by cell-free preparations of $P$. aeruginosa not only suggests the participation of succinate in the degradation of $\gamma$-aminobutyric acid, but also serves as a new route for the biosynthesis of $\gamma$-aminobutyric acid. The reduction of $\gamma$-aminobutyric acid to 4-aminobutan-1-ol and the reversal of this process could also contribute to the biosynthesis and degradation of $\boldsymbol{\gamma}$-aminobutyric acid. The accumulation of 4-aminobutan-1-ol during the degradation of spermidine by Serratia marcescens has already been suggested (Razin et al. 1959). The use of inhibitors may be of help in studying the different stages of $\gamma$-aminobutyric acid degradation. Thus, iodoacetate did not interfere with the transamination reaction, but inhibited the oxidation of succinic semialdehyde. Similar results were obtained with arsenite, which is known to inhibit the oxidation of aldehydes (Jakoby, 1958).

\section{SUMMARY}

1. Extracts of Pseudomonas aeruginosa metabolized $\boldsymbol{\gamma}$-aminobutyric acid by transamination in the presence of $\alpha$-oxoglutarate, pyruvate, oxaloacetate or $\alpha$-oxovalerate.

2. Succinic semialdehyde, produced by transamination, was further oxidized by tri- or diphosphopyridine nucleotide.

3. Succinate was converted into succinic semialdehyde by reduced tri- or di-phosphopyridine nucleotide and yielded $\boldsymbol{\gamma}$-aminobutyric acid by transamination.

4. The formation of 4-aminobutan-1-ol by the reductive amination of succinate, and the forma- tion of $\gamma$-amino $\left[{ }^{14} \mathrm{C}\right]$ butyric acid from $\left[{ }^{14} \mathrm{C}\right]$ succinate, have been described.

\section{REFERENCES}

Albers, R. W. \& Salvador, R. A. (1958). Science, 128, 359.

Bachrach, U., Persky, S. \& Razin, S. (1960). Biochem. J. 76, 306.

Baker, W., Harborne, J. B. \& Ollis, W. D. (1952). J. chem. Soc. p. 3215.

Block, R. J., Durrum, E. L. \& Zweig, G. (1958). A Manual of Paper Chromatography and Paper Electrophoresis, p. 235. New York: Academic Press Inc.

Cavallini, D., Frontali, N. \& Toschi, G. (1949). Nature, Lond., 164, 792.

Chantrenne, H. (1951). J. biol. Chem. 189, 227.

Desker, P. \& Riffart, W. (1950). Chemikerztg, 74, 261. Cited in Chem. Abstr. (1951). 45, 6258.

El Hawary, M. F. S. \& Thompson, R. H. S. (1953). Biochem. $J .53,340$.

Giri, K. V., Radhakrishnan, A. N. \& Vaidyanathan, C. S. (1952). Nature, Lond., 170, 1025.

Highashi, T., Horio, T. \& Okunuki, K. (1957). J. Biochem., Tokyo, 44, 735.

Jakoby, W. B. (1958). J. biol. Chem. 232, 89.

Jakoby, W. B. \& Scott, E. M. (1959). J. biol. Chem. 234, 937.

Kalyankar, G. D. \& Snell, E. E. (1957). Nature, Lond., $180,1069$.

Kojima, K., Mizuno, K. \& Miyazaki, M. (1958). Nature, Lond., 181, 1200.

Layne, E. (1957). In Methods in Enzymology, vol. 3, p. 451. Ed. by Colowick, S. P. \& Kaplan, N. O. New York: Academic Press Inc.

Miller, J. M. \& Rockland, L. B. (1952). Arch. Biochem. Biophys. 40, 416.

Noe, F. F. \& Nickerson, W. J. (1958). J. Bact. 75, 674.

Prescott, B. A. \& Waelsch, H. (1946). J. biol. Chem. 164, 331.

Racker, E. (1950). J. biol. Chem. 184, 313.

Razin, S., Gery, I. \& Bachrach, U. (1959). Biochem. J. 71, 551.

Rosenthal, S. M. \& Tabor, C. W. (1956). J. Pharmacol. 116, 131.

Scott, E. M. \& Jakoby, W. B. (1958). Science, 128, 361.

Tsunoda, T. \& Shiio, I. (1959). J. Biochem., Tokyo, 46, 1011.

Umbreit, W. W., Burris, R. H. \& Stauffer, J. F. (1957). Manometric Techniques and Related Methods for the Study of Tissue Metabolism. Minneapolis: Burgess Publishing Co. 